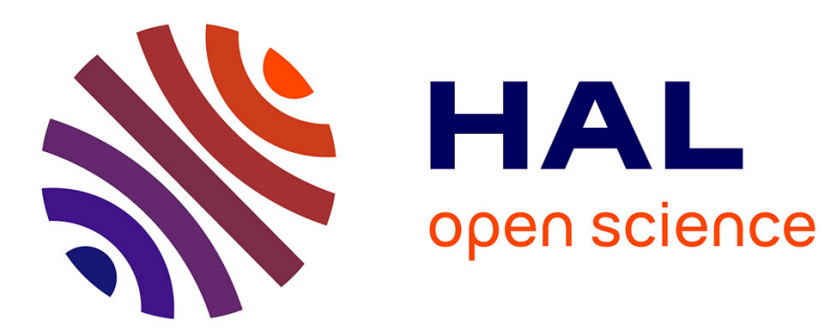

\title{
Structures of UO2, UO2+x andU4O9 by neutron diffraction
}

\author{
B.T.M. Willis
}

\section{To cite this version:}

B.T.M. Willis. Structures of UO2, UO2+x andU4O9 by neutron diffraction. Journal de Physique, 1964, 25 (5), pp.431-439. 10.1051/jphys:01964002505043100 . jpa-00205799

\section{HAL Id: jpa-00205799 https://hal.science/jpa-00205799}

Submitted on 1 Jan 1964

HAL is a multi-disciplinary open access archive for the deposit and dissemination of scientific research documents, whether they are published or not. The documents may come from teaching and research institutions in France or abroad, or from public or private research centers.
L'archive ouverte pluridisciplinaire HAL, est destinée au dépôt et à la diffusion de documents scientifiques de niveau recherche, publiés ou non, émanant des établissements d'enseignement et de recherche français ou étrangers, des laboratoires publics ou privés. 


\title{
STRUCTURES OF $\mathrm{UO}_{2}, \mathrm{UO}_{2+x}$ AND $\mathrm{U}_{4} 0_{9}$ BY NEUTRON DIFFRACTION
}

\author{
By B. T. M. WILLIS,
}

Metallurgy Division, A. E. R. E., Harwell, Didcot, Berks., England.

\begin{abstract}
Résumé. - Des monocristaux ont été étudiés par diffraction neutronique entre $20^{\circ} \mathrm{C}$ et $1100^{\circ} \mathrm{C}$ et dans l'intervalle de composition $\mathrm{UO}_{2}$ à $\mathrm{U}_{4} \mathrm{O}_{9}$. Les recherches se divisent en trois groupes se rapportant à $\mathrm{UO}_{2}, \mathrm{UO}_{2}+x$ (où $0<x<0,25$ ) et $\mathrm{U}_{4} \mathrm{O}_{9}$. $\mathrm{UO}_{2}$ a la structure fluorine à la température ambiante, avec un facteur de Debye-Waller isotrope. A haute température l'arrangement atomique ne peut plus être décrit exactement par la structure fluorine idéale avec des vibrations thermiques harmoniques. Le meilleur accord entre les intensités observées et calculées est obtenu en donnant aux atomes d'oxygène des positions de coordonnées "relaxées " $1 / 4+\delta, 1 / 4+\delta, 1 / 4+\delta$ dans le groupe d'espace $\mathrm{Fm} 3 \mathrm{~m}$ où $\delta$ vaut 0,016 à $1000^{\circ} \mathrm{C}$. L'effet de relaxation peut être interprété en termes soit de désordre, soit d'agitation thermique anharmonique.

En oxydant $\mathrm{UO}_{2}$ en $\mathrm{UO}_{2}+x$, on forme une solution solide, contenant 3 sortes d'atomes d'oxygène, $\mathrm{O}, \mathrm{O}^{\prime}$ et $\mathrm{O}^{\prime \prime}$. Les atomes $\mathrm{O}$ occupent les sites de type fluorine de $\mathrm{UO}_{2}$ mais une partie de ces sites est vide dans $\mathrm{UO}_{2}+x$. Les atomes $\mathrm{O}^{\prime}$ et $\mathrm{O}^{\prime \prime}$ occupent des positions interstitielles qui sont déplacées le long de [110] pour $\mathrm{O}^{\prime}$ et de [111] pour $\mathrm{O}^{\prime \prime}$ à partir des grands vides de la structure fluorine. Les vides eux-mêmes ne sont pas occupés.

A la composition $\mathrm{UO}_{2,25}$, les atomes d'oxygène sont ordonnés pour former une nouvelle phase $\mathrm{U}_{4} \mathrm{O}_{9}$. Les principales réflexions de neutrons de $\mathrm{U}_{4} \mathrm{O}_{9}$ correspondant aux raies de type fluorine de $\mathrm{UO}_{2}$ sont plus fortes que les réflexions de surstructure qui proviennent de l'ordre des atomes d'oxygène interstitiels au sein de la charpente fluorine. L'examen des intensités des principales réflexions montre qu'il y a deux sortes de sites interstitiels, comme dans $\mathrm{UO}_{2+\mathrm{x}}$ : les atomes $\mathrm{O}^{\prime}$ sont placés le long de la direction [110] à $0,85 \AA \AA$ du centre des grandes lacunes, et les atomes $\mathrm{O}^{\prime \prime}$ à $1,05 \AA$ le long de [111]. On trouve des lacunes sur les sites d'oxygène du type fluorine $(O)$, mais non pas sur les sites d'uranium, et la formule chimique $\mathrm{UO}_{2,25}$ est exprimée plus complètement par $\mathrm{U}_{1,00} \mathrm{O}_{1.77} \mathrm{O}_{0,29}^{\prime} \mathrm{O}_{0,19}^{\prime \prime}$.

On en conclut que les atomes d'oxygène ne peuvent pas entrer dans la structure fluorine individuellement mais sont incorporés en petits groupes contenant des atomes $\mathrm{O}^{\prime}$ et $\mathrm{O}^{\prime \prime}$ et des lacunes $\mathrm{O}$. Pour une détermination complète de la structure de $\mathrm{U}_{4} \mathrm{O}_{9}$, il faut attendre l'analyse des réflexions de
\end{abstract} surstructure.

Abstract. - Single crystals have been examined by neutron diffraction in the range of temperatures $20^{\circ} \mathrm{C}$ to $1100^{\circ} \mathrm{C}$ and of compositions $\mathrm{UO}_{2}$ to $\mathrm{U}_{4} \mathrm{O}_{9}$. The investigations divide into three groups, relating to $\mathrm{UO}_{2}, \mathrm{UO}_{2}+x$ (where $0<x<0.25$ ) and $\mathrm{U}_{4} \mathrm{O}_{9}$.

$\mathrm{UO}_{2}$ has the fluorite structure at room temperature, with isotropic Debye-Waller factors. At high temperatures the atomic arrangement can no longer be described exactly in terms of the ideal fluorite structure with harmonic thermal vibrations. Better agreement between observed and calculated intensities is obtained by allowing the oxygen atoms to relax to positions with coordinate $\frac{1}{4}+\delta, \frac{1}{4}+\delta, \frac{1}{4}+\delta \ldots$ in the $\mathrm{Fm} 3 \mathrm{~m}$ space group, where $\delta$ is 0.016 at $1000^{\circ} \mathrm{C}$. The relaxation effect can be interpreted in terms of either disorder or anharmonic thermal motion.

On oxidising $\mathrm{UO}_{2}$ to $\mathrm{UO}_{2}+x$ a solid solution is formed, containing three kinds of oxygen atom, $\mathrm{O}$, $\mathrm{O}^{\prime}$ and $\mathrm{O}^{\prime \prime}$. The $\mathrm{O}^{\prime}$ atoms occupy the fluorite-type sites of $\mathrm{UO}_{2}$, but a proportion of these sites is empty in $\mathrm{UO}_{2}+x$. The $\mathrm{O}^{\prime}$ and $\mathrm{O}^{\prime \prime}$ atoms occupy interstitial positions, which are displaced along $\langle 110\rangle$ (for $\mathrm{O}^{\prime}$ ) and along $<111>$ (for $\mathrm{O}^{\prime \prime}$ ) from the large interstices in the fluorite structure. The interstices themselves are not occupied.

At the composition $\mathrm{UO}_{2.25}$ the oxygen atoms are ordered to form the new phase $\mathrm{U}_{4} \mathrm{O}_{9}$. The " main" neutron reflexions of $\mathrm{U}_{4} \mathrm{O}_{9}$, corresponding to the fluorite-type peaks of $\mathrm{UO}_{2}$, are much stronger than the superlattice reflexions, which arise from the ordering of the interstitial oxygen atoms within the fluorite framework. The analysis of the intensities of the main reflexions shows that there are two kinds of interstitial sites, as in $\mathrm{UO}_{2+\mathrm{x}}$ : the $\mathrm{O}^{\prime}$ atoms are located $0.85 \AA$ along the $\langle 110\rangle$ directions from the centres of the large interstices, and the $\mathrm{O}^{\prime \prime}$ atoms $1.05 \AA$ along $\langle 111\rangle$. Vacancies occur in the fluorite-type oxygen sites $(\mathrm{O})$ but not in the uranium sites, and the chemical formula $\mathrm{UO}_{2.25}$ is expressed more fully as $\mathrm{U}_{\mathbf{1 . 0 0}} \mathrm{O}_{\mathbf{1 . 7 7}} \mathrm{O}_{\mathbf{0}, 29}^{\prime} \mathrm{O}_{\mathbf{0}, 19}^{\prime \prime}$. It is concluded that oxygen atoms cannot enter the fluorite structure individually but are incorporated in small groups containing $\mathrm{O}^{\prime}$ and $\mathrm{O}^{\prime \prime}$ atoms and $\mathrm{O}$ vacancies. A complete structure determination of $\mathrm{U}_{4} \mathrm{O}_{9}$ must await the analysis of the superlattice reflexions.

\section{INTRODUCTION.}

In recent years there have been many fundamental studies of the oxides $\mathrm{UO}_{2}, \mathrm{UO}_{2}+x$ and $\mathrm{U}_{4} \mathrm{O}_{9}$ [1], and the aim of the present work was to determine their crystal structures. The interpretation of thermodynamic and diffusion data, in particular, is critically dependent on knowing the positions of the oxygen atoms, and this knowledge is best gained from neutron diffraction work. 
The structures of the three oxides are interrelated, and so it will be convenient to describe all three here. However, the bulk of the paper concerns $\mathrm{U}_{4} \mathrm{O}_{9}$ only, as the work on $\mathrm{UO}_{2}$ and $\mathrm{UO}_{2+x}$ has already been described elsewhere.

\section{2. $\mathrm{UO}_{2}$.}

At room temperature $\mathrm{UO}_{2}$ has the fluorite structure ( $f g .1$ ), as originally proposed by Goldschmidt in 1923 [2]. The uranium atoms are at the $000 \ldots$ positions of the cubic cell (space group $\mathrm{F} \mathrm{m} 3 \mathrm{~m}$ ) and the oxygen atoms at $\frac{1}{4} \frac{1}{44}, \frac{1}{4} \frac{1}{44} \ldots$. These sites have cubic point symmetry, and the temperature factors $B$ in the Debye-Waller expression $\exp \left(-B \sin ^{2} \theta / \lambda^{2}\right)$ are isotropic. Neutron data on single crystals give $B_{\mathrm{U}}=0.25 \AA^{2}$ $B_{0}=0.43 \AA^{2}[3]$.

Above room temperature the atomic arrangement can no longer be described exactly in terms of the ideal fluorite structure with harmonic thermal vibrations [4]. For Bragg reflexions with $h+k+l$ odd the intensities calculated with this model are proportional to $F^{2}$, where

$$
F=4 b_{\mathrm{U}} \exp \left(-B_{\mathrm{U}} \sin ^{2} \theta / \lambda^{2}\right) .
$$

$b_{U}$ is the nuclear scattering amplitude of uranium, $B_{U}$ the isotropic temperature factor of uranium, $2 \theta$ the scattering angle and $\lambda$ the wavelength. Equation (1) predicts equal intensities for independent reflexions occurring at the same scattering angle, whereas this is not confirmed by observation. Thus the 711 reflexion is stronger than 551,751 is stronger than 555, and the three reflexions 755, 177, 933 have intensities in the order $755>177>933$. Better agreement between observed and calculated intensities is obtained by allowing the oxygen atoms to relax to positions with co-ordinates $\frac{1}{4}+\delta, \frac{1}{4}+\delta, \frac{1}{4}+\delta \ldots$ in the F $m 3 m$ space group. The "relaxation parameter" $\delta$ increases steadily with temperature and is equal to $0.016 \pm 0.001$ at $1000^{\circ} \mathrm{C}$.

There are two alternative explanations of this relaxation effect. In the first, the oxygen atoms are located statistically at the displaced positions, which are four times more numerous than the available number of oxygen atoms. These displaced positions lie along the $\langle 111\rangle$ directions joining the $\frac{1}{4} \frac{1}{4} \frac{1}{4}$ position with the four adjacent interstices at $\frac{111}{222}, \frac{1}{2} 00,0 \frac{1}{2} 0$ and $00 \frac{1}{2}$ (fig. 1). The second interpretation is based on the assumption of asymmetric anharmonic vibration of the oxygen atom. Each oxygen atom has a non-

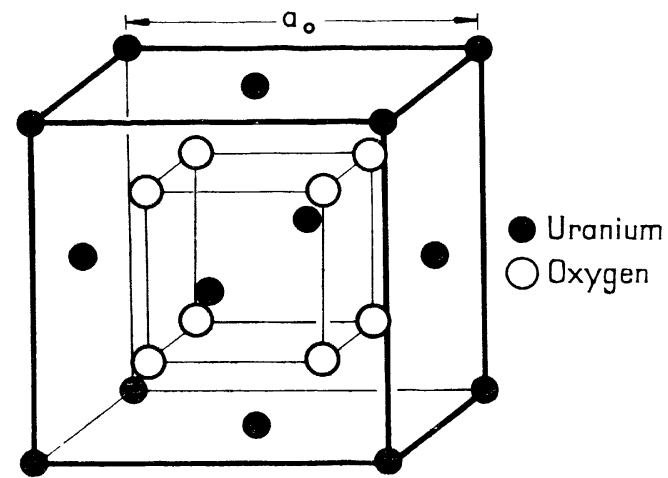

FIG. 1. - Unit cell of $\mathrm{UO}_{2}$ (fluorite-type structure).

centrosymmetric cubic environment, and it is possible that the atom vibrates asymmetrically across its normal position and towards the adjacent interstices (fig. 2). In this case the vibration is anhar-

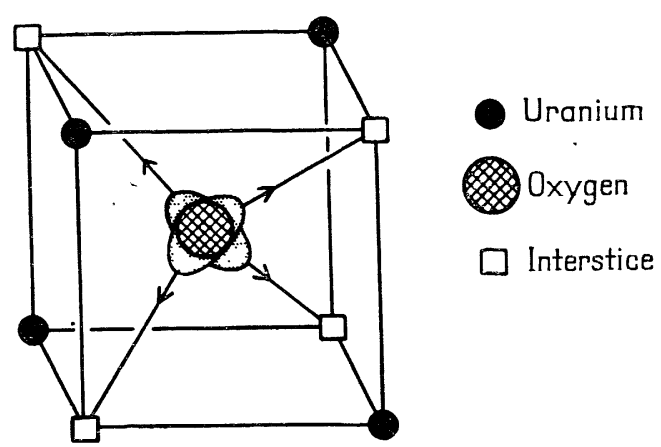

FIG. 2. - Diagram showing extension of the oxygen atom, under the influence of thermal vibration, along $<111>$.

monic and cannot be described by the conventional vibration ellipsoid, specified by six parameters $B_{i j}$, which dégenerate to a single $B_{0}$ for cubic symmetry.

\section{3. $\mathrm{UO}_{2+x}$.}

When $\mathrm{UO}_{2}$ is oxidised at high temperatures a disordered solid solution $\mathrm{UO}_{2+x}$ is formed. The additional oxygen atoms are incorporated at interstitial sites of two kinds, $\mathrm{O}^{\prime}$ and $\mathrm{O}^{\prime \prime}$; the $\mathrm{O}^{\prime}$ atoms are displaced along $<110>$ from the centres of the large interstices in the fluorite structure and the $\mathrm{O}^{\prime \prime}$ atoms along $<111>$. Vacancies exist in the fluorite-type positions, and the interstices themselves are not occupied. These conclusions were derived from the analysis of two-dimensionall $\mathrm{F}_{h k k}$ data, collected from a crystal of $\mathrm{UO}_{2 \cdot 13}$ at $800{ }^{\circ} \mathrm{C}$ [5], and were later confirmed by athree-dimensional study [15]. 


\section{4. $\mathrm{U}_{4} \mathbf{0}_{9}$ : ANALYSIS OF MAIN BRAGG REFLEXIONS.}

4.1. Introduction. - Alberman and Anderson [6] first recognised the existence of a phase of uranium oxide, whose structure is closely related to that of $\mathrm{UO}_{2}$ but which has higher oxygen content. Héring and Pério [7] showed that the composition of this phase is close to $\mathrm{UO}_{2 \cdot 25}$, but more recent work $[8,9]$ has shown that there is a composition range trom $\mathrm{UO}_{2 \cdot 23}$ to $\mathrm{UO}_{2 \cdot 25}$ at high temperatures, with the possibility of a narrower range at room temperature. Thus the phase $\mathrm{U}_{4} \mathrm{O}_{9}$ should be designated $\mathrm{U}_{4} \mathrm{O}_{9-y}$; it will be referred to below simply as $\mathrm{U}_{4} \mathrm{O}_{9}$, except where the precise composition is discussed.

Belbeoch, Piekarski and Pério [10] have interpreted the oxidation of $\mathrm{UO}_{2}$ to $\mathrm{U}_{4} \mathrm{O}_{9}$ in the following way. At high temperatures oxygen atoms enter the $\mathrm{UO}_{2}$ structure interstitially and in a statistically disordered fashion; the process continues up to the limiting composition $\mathrm{UO}_{2 \cdot 25}$, and then on cooling the interstitial oxygens are redistributed to form an ordered $\mathrm{U}_{4} \mathrm{O}_{9}$ phase at room temperature with an enlarged unit cell. This interpretation is supported by density measurements, which rule out the existence of vacancies in the uranium sub-lattice, and by X-ray diffraction data. The $\mathrm{X}$-ray examination of $\mathrm{U}_{4} \mathrm{O}_{9}$ shows that the fluorite-type reflexions of $\mathrm{UO}_{2}$ remain after oxidation, with a slight increase in the scattering angles, and that very weak superlattice lines appear. Belbeoch et al. found that the crystal system remains cubic on oxidation, with a reduction in space-group symmetry from $\mathrm{Fm} 3 \mathrm{~m}\left(\mathrm{UO}_{2}\right)$ to $\bar{I} \overline{4} d\left(\mathrm{U}_{4} \mathrm{O}_{9}\right)$ and with an increase in the size of the unit cell to $21.8 \AA$ for $\mathrm{U}_{4} \mathrm{O}_{9}$, four times the cell size for $\mathrm{UO}_{2}$. They proposed a complete structure for the $21.8 \AA$ cell, without using the conventional method of measuring structure factors. This structure is not compatible with the neutron diffraction results described below.

The neutrons reflexions divide into two groups : the very weak and numerous superlattice reflexions and the " main " or fluorite-type reflexions. Broadly speaking, the main reflexions represent scattering from all the atoms in the unit cell, whereas the superlattice reflexions are contributed by interstitial oxygen atoms alone. Apart from the determination of space group, which requires identifying all kinds of reflexion, this paper is concerned only with the measurement and interpretation of the main reflexions.

4.2. Space group of unit cell. - A single crystal, A, weighing $520 \mathrm{mg}$ was prepared from a single crystal of $\mathrm{UO}_{2}$ by heating for one month at $1150^{\circ} \mathrm{C}$ in the presence of powdered $\mathrm{U}_{3} \mathrm{O}_{8}$. The $\mathrm{UO}_{2}$ crystal was placed in one arm of an evacuated silica $\mathrm{H}$-tube and the powder in the other arm, so that oxidation occurred sia the vapour phase. Measurement of the oxygen potential with a hightemperature galvanic cell [11] showed that crystal A was single-phase, within the narrow homogeneity range of the $\mathrm{U}_{4} \mathrm{O}_{9-y}$ phase, at temperatures above $650^{\circ} \mathrm{C}$. The composition is thus close to $\mathrm{UO}_{2 \cdot 25}$.

The crystal was mounted"on a three-circle neutron diffractometer and reciprocal space was scanned in lines through the origin along [100], $[010],[001],[110] \ldots,[111] \ldots,[211] \ldots$, $[321] . . .$, where the indices refer to the orthogonal axes of the $21.8 \AA$ cell. Forty-six main reflexions and over one hundred superlattice reflexions were observed. All these reflexions indexed satisfactorily on a cubic $4 \mathrm{a}_{0}$ cell, with $a_{0}=5.44 \AA$. For a given set of indices $\{h k l\}$, the superlattice reflexions with different signs and order of indices were equivalent in intensity : this indicates that the unit cell is cubic with Laue symmetry $m 3 m . h+k+l$ was even for all observed reflexions, so that the lattice is body-centred. Because of their weak intensity, only one in ten of the superlattice reflexions for a body-centred $4 a_{0}$ cell were detected, but the indices of all observed reflexions were consistent with the $I \overline{4} 3 d$ space group.

This space group and cell size of $4 \mathrm{a}_{0}$ are in accordance with the X-ray results of Belbeoch et al. [10] and will be adopted below. They are in disagreement with the conclusions of Steeb [12] based on the electron diffraction examination of a thin film of $\mathrm{U}_{4} \mathrm{O}_{9}$.

4.3. Space group of composite cell. - The nuclear density $\rho(X Y Z)$ at any point $X Y Z$ in the unit cell can be computed from the neutron structure factors $F_{h k l}$ using the equation :

$\rho(X Y Z)=\frac{1}{V} \sum_{h} \sum_{\sum_{-\infty}}^{\infty} \sum_{l} F_{h k l} \exp [-2 \pi i(h X+k Y+l Z)]$,

where $V$ is the volume of the unit cell. For the main reflexions $h, k, l$ are all multipes of four, and if the summation in (2) is restricted to all indices divisible by four, the computed density $\rho^{\prime}(X Y Z)$ is :

$\rho^{\prime}(X Y Z)=\frac{1}{V} \sum_{h, k, l} \sum_{l=4 n} F_{h k l} \exp [-2 \pi i(h X+k Y+l Z)]$

$\rho^{\prime}(X Y Z)$ is derived from $\rho(X Y Z)$ by superimposing the contents of the sixty-four subcells, each of side $a_{0}$, contained in the unit cell of side $4 a_{0}$. Expressed formally :

$$
\begin{gathered}
\rho^{\prime}(X Y Z)=\frac{1}{64}\left[\rho(X Y Z)+\rho\left(X+\frac{1}{4}, Y, Z\right)\right. \\
+\rho\left(X+\frac{1}{2}, Y, Z\right)+\rho\left(X+\frac{3}{4}, Y, Z\right)
\end{gathered}
$$




$$
\begin{aligned}
& +\rho\left(X, Y+\frac{1}{4}, Z\right)+\rho\left(X+\frac{1}{4}, Y+\frac{1}{4}, Z\right) \\
& +\rho\left(X+\frac{1}{2}, Y+\frac{1}{4}, Z\right)+\rho\left(X+\frac{3}{4}, Y+\frac{1}{4}, Z\right) \\
& +\ldots \ldots \ldots \ldots \\
& +\rho\left(X, Y+\frac{3}{4}, Z+\frac{3}{4}\right)+\rho\left(X+\frac{1}{4}, Y+\frac{3}{4}, Z+\frac{3}{4}\right) \\
& +\rho\left(X+\frac{1}{2}, Y+\frac{3}{4}, Z+\frac{3}{4}\right) \\
& \left.+\rho\left(X+\frac{3}{4}, Y+\frac{3}{4}, Z+\frac{3}{4}\right)\right],
\end{aligned}
$$

an equation in 64 terms which is readily derived from equations (2) and (3). $\rho^{\prime}(X Y Z)$ represents the contents of the " composite cell " of side $a_{0}$.

It is found experimentally that only one or two very weak superlattice reflexions with $h, k, l=4 n$ can be detected. $\quad \rho$ ' in equation (3) can be approximated, therefore, by a summation, which includes the main reflexions only:

$\rho^{\prime}(X Y Z)=\frac{1}{V} \sum \sum_{\text {reflexions }} \sum F_{h k l} \exp [-2 \pi i(h X+k Y+l Z)]$.

If the indices $h k l$ in (4) are replaced by $h^{\prime} k^{\prime} l^{\prime}$, where $h^{\prime}=h / 4, k^{\prime}=k / 4, l^{\prime}=l / 4$, the co-ordinates $X Y Z$ represent fractional lengths of the axes of the composite cell.

The space group for the distribution $\rho(X Y Z)$ is $\overline{4} 33 d$. In reducing the cell edge from $4 a_{0}$ for the true cell to $a_{0}$ for the composite cell, $I$ (bodycentred) is transformed to $P$ (primitive) and the diagonal glide $d$ is changed to $m$ (mirror plane). Thus the space group of the composite cell is $P \overline{\mathbf{4}} 3 \mathrm{~m}$. However, $h^{\prime} k^{\prime} l^{\prime}$ reflexions of mixed indices are either absent or only barely detectable, so that the lattice type is approximately $F$ (face-centred) and the space group for $\rho^{\prime}$, as defined by equation (4), is $F \overline{4} 3 \mathrm{~m}$. This space group will be used to analyse the main reflexions.

4.4. Experimental data. - The intensities of the main reflexions of crystal A were measured with a three-circle diffractometer. Forty-six independent reflexions were measured up to

$$
h^{\prime 2}+k^{\prime 2}+l^{\prime 2}=100
$$

with a neutron wavelength of $1.04 \AA$. As in the case of $\mathrm{UO}_{2}$, these reflexions can be classified into three groups, which are weak, medium or strong depending on whether $h^{\prime}+k^{\prime}+l^{\prime}=4 n+2,4 n \pm 1$ or $4 n$. Previous experience [3] suggested that the strong reflexions are subject to systematic errors from secondary extinction, and the weak reflexions to errors from double Bragg scattering. Fortunately, both errors proved to be small. Examination of the intensities from crystal $A$, varying both the incident wavelength and the path length of the beam inside the crystal, showed that there was no appreciable extinction and that multiple scattering was less pronounced than for $\mathrm{UO}_{2}$. The widths of the rocking curves of crystal $A$ were greater than for the $\mathrm{UO}_{2}$ crystal from which it was prepared : this indicates that the entry of interstitial oxygen atoms strains the crystal and increases its mosaic spread to a point at which the two systematic errors referred to above are no longer significant.

A second crystal, B, weighing $490 \mathrm{mg}$ and with the same composition as A, was examined also. The structure factors $|F|$ for the two crystals agreed to within a few per cent. Later, crystal A was re-measured with the Harwell Mark $I$ automatic diffractometer [13], the observations being repeated for eight equivalent reflexions of each $\left\{h^{\prime} k^{\prime} l^{\prime}\right\}$ set. Table I lists the observed values of $F$, averaged for the measurements on both crystals, together with the standard deviations $\sigma(F)$ of $F$. These $\sigma$ 's were estimated from the variations in the individual measurements; they are appreciably greater than the random errors from the statistics of pulse counting, and represent uncertainties arising from other sources, such as non-uniformity of the incident neutron beam.

4.5. Analysis of data. - The similarity of the $\mathrm{X}$-ray patterns of $\mathrm{UO}_{2}$ and $\mathrm{U}_{4} \mathrm{O}_{9}$ [10] suggests that the fluorite structure can be adopted as the first model in refining the data in Table I by leastsquares methods. For the space group $F \overline{4} 3 m$ this model requires placing the uranium atoms at the (d) positions (International Tables, Volume I) of four fold multiplicity

$$
4(d)=\frac{33}{4} \frac{3}{4}, \quad \frac{31}{4} \frac{1}{4}, \quad \frac{1}{4} \frac{3}{4} \frac{1}{4}, \quad \frac{11}{4} \frac{3}{4},
$$

half the oxygen atoms at

$$
4(a)=000, \quad 0 \frac{1}{2} \frac{1}{2}, \quad \frac{1}{2} 0 \frac{1}{2}, \quad \frac{1}{2} \frac{1}{2} 0,
$$

and the other half at

$$
4(b)=\frac{1}{2} \frac{1}{2} \frac{1}{2}, \quad \frac{1}{2} 00, \quad 0 \frac{1}{2} 0, \quad 00 \frac{1}{2} .
$$

The origin of the cell is occupied by an oxygen atom, although in the fluorite structure it is more usual to choose the origin at a uranium atom (fig. 1). In the least-squares refinement the scale factor and the individual isotropic temperature factors of uranium and oxygen $\left(B_{\mathrm{U}}, B_{\mathrm{O}}\right)$ were treated as adjustable parameters. The results are presented under model 1 in Table II, which shows that the reliability factor

$$
R=\Sigma|| F_{0}|-| F_{\mathrm{c}}|\div \Sigma| F_{0} \mid
$$

is already less than $16 \%$. The Least Squares pro.gramme of Busing, Martin and Levy [14] was used for this and later calculations. 
TABLE I

Neutron diffraction data for $\mathrm{U}_{4} \mathrm{O}_{9}$. Main reflexions only.

\begin{tabular}{|c|c|c|c|c|c|c|c|}
\hline & $h k l$ & & $h^{\prime} k^{\prime} l^{\prime}$ & $\left|F_{\mathrm{obs}}\right|$ & $\left|F_{\text {calc }}\right|$ & ||$F_{\text {obs }}|-| F_{\text {calc }}||$ & $\sigma\left(F_{\text {obs }}\right)$ \\
\hline & 008 & & 002 & 57 & 38 & 19 & 6 \\
\hline 0 & 0 & 16 & 004 & 650 & 658 & 8 & 21 \\
\hline 0 & 0 & 24 & 006 & 76 & 49 & 27 & 16 \\
\hline 0 & 0 & 32 & 008 & 513 & 519 & 6 & 6 \\
\hline 0 & 0 & 40 & $\begin{array}{lll}0, & 0, & 10\end{array}$ & 108 & 113 & 5 & 4 \\
\hline & 444 & & 111 & 323 & 324 & 1 & 7 \\
\hline 4 & 4 & 12 & 113 & 364 & 382 & 18 & 5 \\
\hline 4 & 4 & 20 & 115 & 355 & 350 & 5 & 7 \\
\hline 4 & 4 & 28 & 117 & 269 & 266 & 3 & 10 \\
\hline 4 & 4 & 36 & 119 & 207 & 231 & 24 & 7 \\
\hline & 880 & & 220 & 780 & 773 & 7 & 7 \\
\hline & 888 & & 222 & 49 & 52 & 3 & 10 \\
\hline 8 & 8 & 16 & 224 & 648 & 655 & 27 & 5 \\
\hline 8 & 8 & 24 & 226 & 70 & 56 & 14 & 7 \\
\hline 8 & 8 & 32 & 228 & 445 & 438 & 7 & 10 \\
\hline 12 & 12 & 4 & 331 & 352 & 340 & 12 & 6 \\
\hline 12 & 12 & 12 & 333 & 333 & 321 & 12 & 6 \\
\hline 12 & 12 & 20 & 335 & 308 & 294 & 14 & 5 \\
\hline 12, & 12 & 28 & 337 & 273 & 265 & 8 & 4 \\
\hline 12 & 12 & 36 & 339 & 207 & 229 & 22 & 6 \\
\hline 16 & 8 & 0 & 420 & 46 & 24 & 22 & 5 \\
\hline 16 & 16 & 0 & 440 & 628 & 635 & 7 & 5 \\
\hline 16 & 16 & 8 & 442 & 70 & 46 & 24 & 3 \\
\hline 16 & 16 & 16 & 444 & 554 & 550 & 4 & 4 \\
\hline 16 & 16 & 24 & 446 & 113 & 98 & 15 & 4 \\
\hline 16 & 16 & 32 & 448 & 375 & 366 & 9 & 7 \\
\hline 20 & 12 & 4 & 531 & 324 & 316 & 8 & 5 \\
\hline 20 & 20 & 4 & 551 & 280 & 292 & 12 & 5 \\
\hline 20 & 20 & 12 & 553 & 279 & 269 & 10 & 5 \\
\hline 20 & 20 & 20 & 555 & 239 & 248 & 9 & 7 \\
\hline 20 & 20 & 28 & 557 & 221 & 227 & 6 & 4 \\
\hline 24 & 8 & 0 & 620 & 573 & 575 & 2 & 6 \\
\hline 24 & 16 & 0 & 640 & 56 & 48 & 8 & 12 \\
\hline 24 & 16 & 8 & 642 & 521 & 502 & 19 & 6 \\
\hline 24 & 24 & 0 & 660 & 452 & 436 & 16 & 6 \\
\hline 24 & 24 & 8 & 662 & 106 & 93 & 13 & 8 \\
\hline 24 & 24 & 16 & 664 & 384 & 385 & 1 & 12 \\
\hline 28 & 12 & 4 & 731 & 278 & 295 & 17 & 4 \\
\hline 28 & 20 & 4 & 751 & 258 & 270 & 12 & 4 \\
\hline 28 & 20 & 12 & $753^{\circ}$ & 242 & 246 & 4 & 5 \\
\hline 28 & 28 & 4 & 771 & 215 & 215 & 0 & 12 \\
\hline 32, & 8 & 0 & 820 & 89 & 93 & 4 & 10 \\
\hline 32, & 16 & 0 & 840 & 396 & $38^{4}$ & 12 & 5 \\
\hline 32, & 16 & 8 & 842 & 87 & 91 & 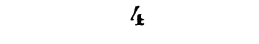 & 7 \\
\hline 32, & 24 & 0 & 860 & 99 & 114 & 15 & 7 \\
\hline 36 & 12 & 4 & 931 & 235 & 246 & 11 & 4 \\
\hline
\end{tabular}


In model 2 another adjustable parameter was introduced, viz. the " occupation number" $p_{\mathbf{a}}$ of the atoms in the $4(a)$ sites. For $p_{\mathrm{a}}=1$ the fluorite positions are fully occupied, as in $\mathrm{UO}_{2}$, but for $p_{\mathrm{a}}$ less than unity a fraction $1-p_{\mathrm{a}}$ of the $4(a)$ sites is empty. $R$ improved slightly (Table II)

TABLE II

Least-squares Refinement (MOdels 1 and 2)

\begin{tabular}{|c|c|c|c|c|}
\hline & TYPE & $\begin{array}{c}\text { Site } \\
\text { OGCUPATION }\end{array}$ & TEMPERATURE & $R$ FACTOR \\
\hline & OF ATOM & NUMBER, $p$ & FACTOR $\left(\AA^{2}\right)$ & \\
\hline Model 1 & $\mathrm{U}$ & 1.00 & 0.52 & \\
\hline & $\mathrm{O}^{a}$ & 1.00 & 1.54 & \\
\hline & $\mathrm{O}^{b}$ & 1.00 & 1.54 & 0.159 \\
\hline Model 2 & $\mathrm{U}$ & 1.00 & 0.60 & \\
\hline & $\mathrm{O} a$ & 0.65 & 1.57 & \\
\hline & $\mathrm{O}^{b}$ & 1.00 & 1.57 & 0.147 \\
\hline
\end{tabular}

and $p_{\mathrm{a}}$ was reduced to 0.65 . As the $4(a)$ and $4(b)$ sites are equivalent in the fluorite structure, model 2 can be used to refine $p_{\mathrm{a}}+p_{\mathrm{b}}$ only and not $p_{\mathrm{a}}, p_{\mathrm{b}}$ independently. Thus the same results are obtained in model 2 with $p_{\mathrm{a}}=1$ and $p_{\mathrm{b}}=0.65$.

For the next calculation the ninth oxygen atom in the formula unit $\mathrm{U}_{4} \mathrm{O}_{9}$, ignored in models 1 and 2 , was placed at the position :

$$
4(c)=\frac{1}{4} \frac{1}{4} \frac{1}{4}, \quad \frac{1}{4} \frac{3}{4} \frac{3}{4}, \quad \frac{3}{4} \frac{1}{4} \frac{3}{4}, \quad \frac{3}{4} \frac{3}{4} \frac{1}{4}
$$

of the composite cell. These are the sites of the large interstices in the fluorite structure, and were assumed by Belbeoch et al. [10] to be occupied by the interstitial oxygen atoms. However, no satisfactory refinement of the neutron data was possible with this model. All attempts at refinement led to the rejection of the ninth atom from the $4(c)$ position.

At this stage it was decided to carry out a threedimensional Fourier synthesis, of the type described by equation (4), in the hope of locating the lost oxygen atoms. The phases of the observed structure factors $F_{\text {obs }}$ were taken as those calculated for model 2. The nuclear density plot was dominated by strong peaks due to the oxygen and uranium atoms at fluorite positions, but there was no indication of other peaks which could be ascribed definitely to oxygen. *

The interstitial oxygen atoms were finally located by difference Fourier syntheses. Figure 3 is a section of the difference map at height $Z=3 / 8$ of the composite cell ; the coefficients in the Fourier summation were derived from the observed structure factors and those calculated for model 2 . The atoms at fluorite positions were not present on' the difference map, and the peaks, labelled $h$ and $e$ in figure 3 , represent interstitial oxygen atoms at two

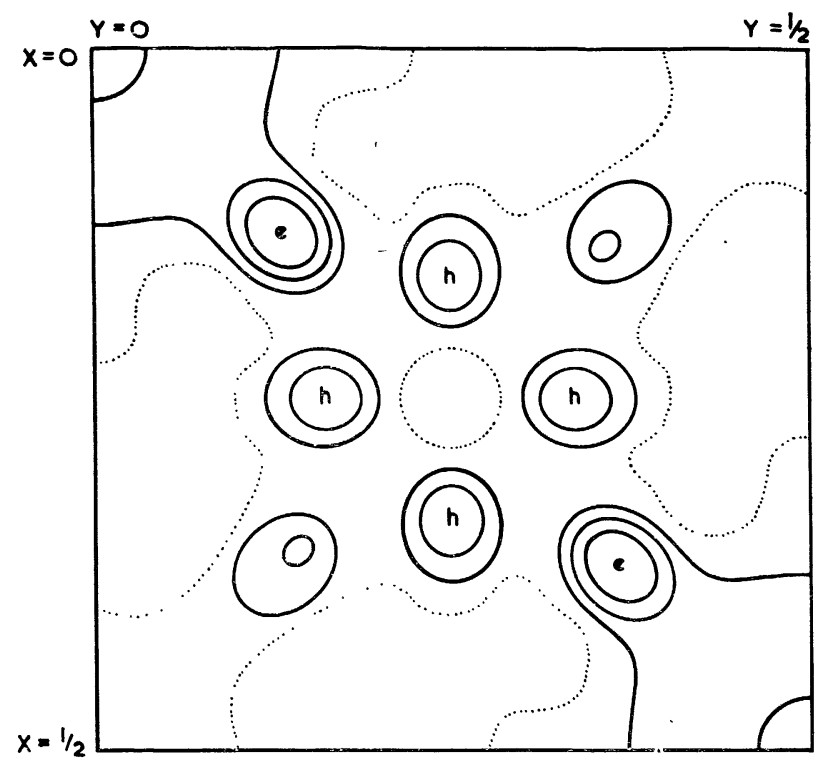

Fig. 3. - Section of Fourier difference map at height $Z=3 / 8$ of composite cell, with uranium and fluorite-type oxygens removed. The peaks $h$ are interstitial oxygens $\mathrm{O}^{\prime}$ at $48(h)$ sites and $e$ are interstitial oxygens $\mathrm{O}^{\prime \prime}$ at 16(e) sites. Zero contour shown dotted.

kinds of crystallographic site. $\mathrm{O}^{\prime}$ atoms are at positions :

$$
\begin{aligned}
48(h)= & \left(\begin{array}{llll}
0 & 0 & 0 & 0
\end{array} \frac{1}{2} \frac{1}{2}, \quad \frac{1}{2} 0 \frac{1}{2}, \quad \frac{1}{2} \frac{1}{2} 0\right) \\
& +\left(\frac{1}{4}+\varepsilon^{\prime} \quad \frac{1}{4}+\varepsilon^{\prime} \quad \frac{1}{4}\right),\left(\frac{1}{4}+\varepsilon^{\prime} \quad \frac{1}{4} \frac{1}{4}+\varepsilon^{\prime}\right)
\end{aligned}
$$

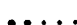

and $\mathrm{O}^{\prime \prime}$ atoms at :

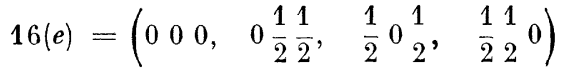

$$
\begin{aligned}
& +\left(\begin{array}{l}
1 \\
4
\end{array}+\varepsilon^{\prime \prime} \frac{1}{4}+\varepsilon^{\prime \prime} \frac{1}{4}+\varepsilon^{\prime \prime}\right),\left(\begin{array}{lll}
\frac{1}{4}+\varepsilon^{\prime \prime} & \frac{3}{4}-\varepsilon^{\prime \prime} & \frac{3}{4}-\varepsilon^{\prime \prime}
\end{array}\right)
\end{aligned}
$$

where

$$
\left|\varepsilon^{\prime}\right| \approx\left|\varepsilon^{\prime \prime}\right| \approx \frac{1}{8} .
$$

Figure 4 is a drawing showing the relation of the $48(h)$ and $16(e)$ sites to the cube of eight fluorite-type oxygens.

The difficulty of locating the ninth oxygen atom in the full Fourier synthesis can be ascribed now to the large number of equivalent $\mathrm{O}^{\prime}$ and $\mathrm{O}^{\prime \prime}$ sites. This atom is distributed statistically in 'sites of eight-fold and sixteen-fold multiplicity, whereas the remaining oxygens occupy fluorite positions of only four-fold multiplicity.

The interstitial oxygens were placed at $48(h)$ and $16(e)$ sites for the least-squares refinement with model 3 (see Table III). Seven parameters were 
TABLE III

LEAST-SQUARES REFINEMENT (MODEL 3)

\begin{tabular}{|c|c|c|c|c|}
\hline TYYPE & OF ATOM & $\begin{array}{l}\text { ATOMIC CO-ORDINATES } \\
\text { IN GOMPOSITE GELL }\end{array}$ & $\begin{array}{l}\text { SITE OCCUPATION } \\
\text { NUMBER, } p\end{array}$ & $\begin{array}{l}\text { NUMBER OF ATOMS } \\
\text { IN } 21.8 \AA \text { GELL }\end{array}$ \\
\hline & $\mathrm{U}$ & $\frac{1}{4} \frac{1}{4} \frac{1}{4}$ & - & - \\
\hline & $\mathrm{O}^{a}$ & 000 & $0.81 \pm 0.22$ & \multirow[b]{2}{*}{$453 \pm 5$} \\
\hline & $\mathrm{O}^{b}$ & $\frac{1}{2} \frac{1}{2} \frac{1}{2}$ & $0.96 \pm 0.24$ & \\
\hline & $\mathrm{O}^{\prime}$ & $\frac{1}{4}+\varepsilon^{\prime} \frac{1}{4}$ & $0.024 \pm 0.004$ & $73 \pm 11$ \\
\hline & $\mathrm{O}^{\prime \prime}$ & $\frac{1}{4}+\varepsilon^{\prime \prime} \frac{1}{4}+\varepsilon^{\prime \prime} \frac{1}{4}+\varepsilon^{\prime \prime}$ & $0.016 \pm 0.003$ & $48 \pm 8$ \\
\hline
\end{tabular}

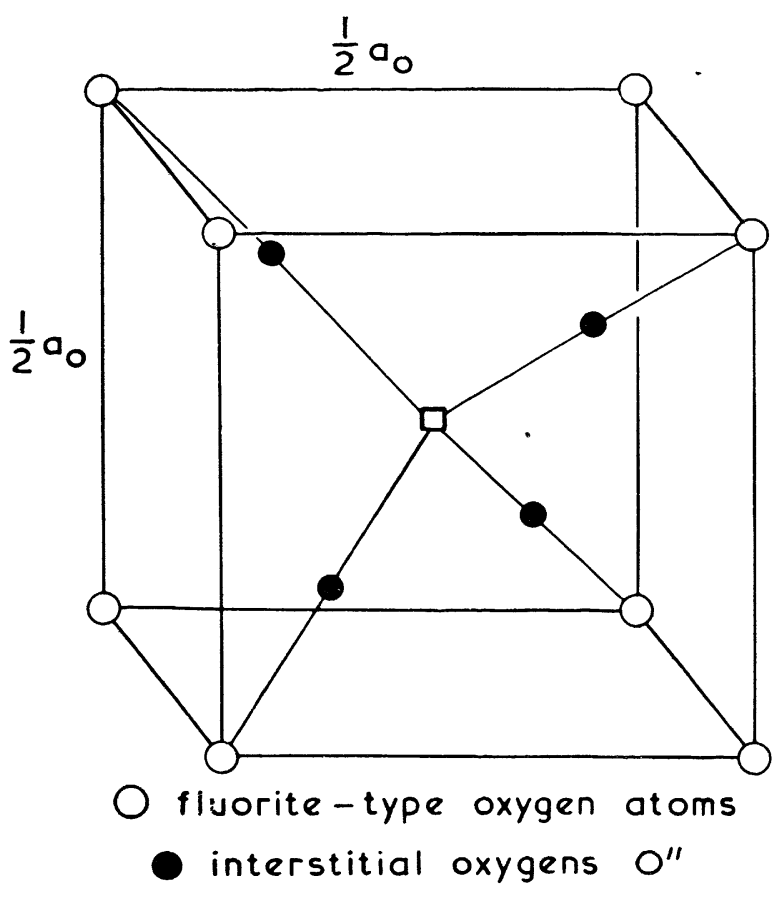

$a$

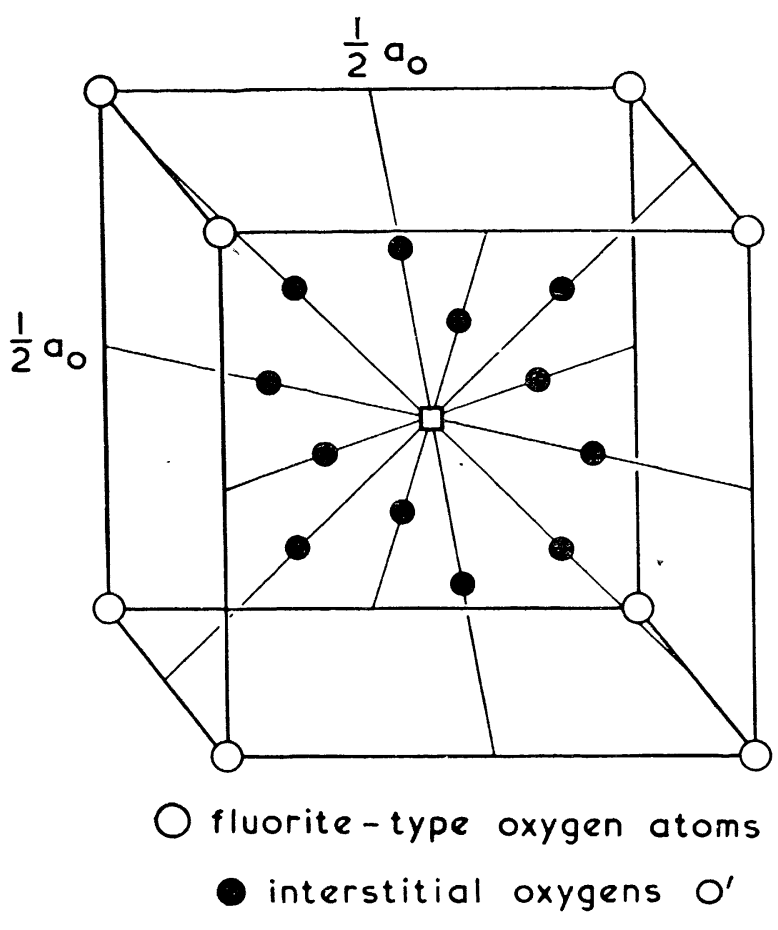

$b$

FIG. 4. - Composite cell of $\mathrm{U}_{4} \mathrm{O}_{9}$ showing interstitial oxygen atoms at $\left.a\right) \mathrm{O}^{\prime}$ sites, b) $\mathrm{O}^{\prime \prime}$ sites. The large interstice is at the centre of the cube of fluorite-type oxygens. The $O^{\prime}$ oxygens are half way between the interstice and the mid-point of the cube edges; the $\mathrm{O}^{\prime \prime}$ oxygens are half way from the interstice to the cube corners.

refined : the two positional co-ordinates, $\varepsilon^{\prime}$ and $\varepsilon^{\prime \prime}$, the occupation numbers of the $4(a)$ sites (normal oxygen $\mathrm{O}^{\mathrm{a}}$ ), $4(\mathrm{~b})$ (normal oxygen $\mathrm{O}^{\mathrm{b}}$ ), 48(h) (interstitial oxygen $\mathrm{O}^{\prime}$ ) and 16(e) (interstitial oxygen $\mathrm{O}^{\prime \prime}$ ), and the overall scale factor.

The temperature factors were kept fixed at the values given by model 2 . Table III gives the results of the calculation, together with the estimated standard errors of the refined parameters. These parameters gave the $F_{\text {calc }}$ column in Table I.
Later, separate refinement of the temperature factors gave no significant changes from $B_{\mathrm{U}}=0.60 \AA^{2}$ and $B_{0}=1.57 \AA^{2}$.

The following features of the oxidation process, $\mathrm{UO}_{2}$ to $\mathrm{U}_{4} \mathrm{O}_{9}$, can be deduced from the refinement of model 3 :

(1) The isotropic temperature factor at $20{ }^{\circ} \mathrm{C}$ increases trom $0.25 \AA^{2}$ for $\mathrm{UO}_{2}$ [3] to $0.60 \AA^{2}$ for $\mathrm{U}_{4} \mathrm{O}_{9}$. If the whole of this increase, $\Delta B$, is attributed to displacements of the uranium atoms 
from the fluorite positions, the r. m. s. displacement in any direction is $\sqrt{\Delta B / 8 \pi^{2}}=0.06 \AA$.

(2) Oxidation proceeds by the incorporation of interstitial oxygen atoms at $\mathrm{O}^{\prime}$ and $\mathrm{O}^{\prime \prime}$ sites. $\mathrm{O}^{\prime}$ atoms are located $0.86 \AA\left(=\sqrt{2} \varepsilon^{\prime} a_{0}\right)$ along the $\langle 110\rangle$ directions from the centres of the large interstices at $4(c) ; \mathrm{O}^{\prime \prime}$ atoms occupy positions $1.05 \AA\left(=\sqrt{3} \varepsilon^{\prime \prime} a_{0}\right)$ along the $\langle 111\rangle$ directions from $4(c)$ (see fig. 4).

(3) The incorporation of interstitial atoms is accompanied by the ejection of oxygen atoms from fluorite positions. Approximately one in ten of the normal oxygens are displaced to $\mathrm{O}^{\prime}$ or $\mathrm{O}^{\prime \prime}$ sites.

\section{CONCLUSIONS.}

The atomic arrangement in the composite cell of $\mathrm{U}_{4} \mathrm{O}_{9}$ is similar to that in the average cell of the disordered oxide $\mathrm{UO}_{2 \cdot 13}[5]$. In both cases interstitial oxygen atoms occupy $\mathrm{O}^{\prime}$ and $\mathrm{O}^{\prime \prime}$ sites and vacancies occur in the fluorite sites of the normal oxygens. This suggests that oxygen atoms cannot be incorporated singly in the fluorite structure, but only in groups containing $\mathrm{O}^{\prime}$ and $\mathrm{O}^{\prime \prime}$ atoms and $\mathrm{O}$ vacancies.

There are two important differences between $\mathrm{UO}_{2 \cdot 13}$ and $\mathrm{U}_{4} \mathrm{O}_{9}$. First, the normal oxygen atoms in $\mathrm{U}_{4} \mathrm{O}_{9}$ show little tendency to relax along $\langle 111\rangle$ towards the centres of the large interstices. This relaxation effect in $\mathrm{UO}_{2 \cdot 13}$ can be attributed (as for $\mathrm{UO}_{2}$ at high temperatures [4]) to disorder or to anharmonic thermal motion. Second, the space-group symmetry $(\overline{F 43 m})$ of the composite cell of $\mathrm{U}_{4} \mathrm{O}_{9}$ is lower than the symmetry $(F m 3 m)$ of $\mathrm{UO}_{2+x}$, so that the two interpenetrating sub-lattices, $\mathrm{O}^{\mathrm{a}}$ and $\mathrm{O}^{\mathrm{b}}$, can be distinguished in $\mathrm{U}_{4} \mathrm{O}_{9}$. However, there is a very high correlation between the occupation numbers $p_{\mathrm{a}}$ and $p_{\mathrm{b}}$ for model 3 , and this is reflected in the high standard errors of these quantities.

Assuming that the fluorite positions $4(d)$ of the uranium atoms are fully occupied, the unit cell of the crystal with the exact composition $\mathrm{U}_{4} \mathrm{O}_{9}$ contains 256 uranium and 576 oxygen atoms. The results in Table III show that the unit cell contains 256 uranium and 572 oxygen atoms, and that the chemical formula is expressed more fully as

$$
\mathrm{U}_{1.00} \mathrm{O}_{0.81 \pm 0.22}^{\mathrm{a}} \mathrm{O}_{0.96 \pm 0.24}^{\mathrm{b}} \mathrm{O}_{0.29 \pm 0.05}^{\prime} \mathrm{O}_{0.19 \pm 0.04}^{\prime \prime}
$$

Because of the high correlation between $p_{\mathrm{a}}$ and $p_{\mathrm{b}}$ the least-squares refinement for model 3 was repeated with $p_{\mathrm{a}}$ fixed at the value given in Table III. This led to a reduction in the standard error tor $p_{\mathrm{b}}$ (see last column of Table III) and the chemical formula worked out as :

$$
\begin{array}{llll}
\mathrm{U}_{1.00} & \mathrm{O}_{1.77 \pm 0.02} & \mathrm{O}_{0,29 \pm 0.04}^{\prime} \mathrm{O}_{0.19 \pm 0}^{\prime \prime} 03
\end{array}
$$

where $\mathrm{O}$ represents $\mathrm{O}_{\mathbf{a}}$ and $\mathrm{O}_{\mathbf{b}}$ atoms together.
The standard errors in the occupation numbers $p$ are quite high, and the close agreement with the chemical composition $\mathrm{UO}_{2 \cdot 25}$ may be fortuitous. Clearly, extremely accurate intensity data are required to determine the $p^{\prime}$ s precisely.

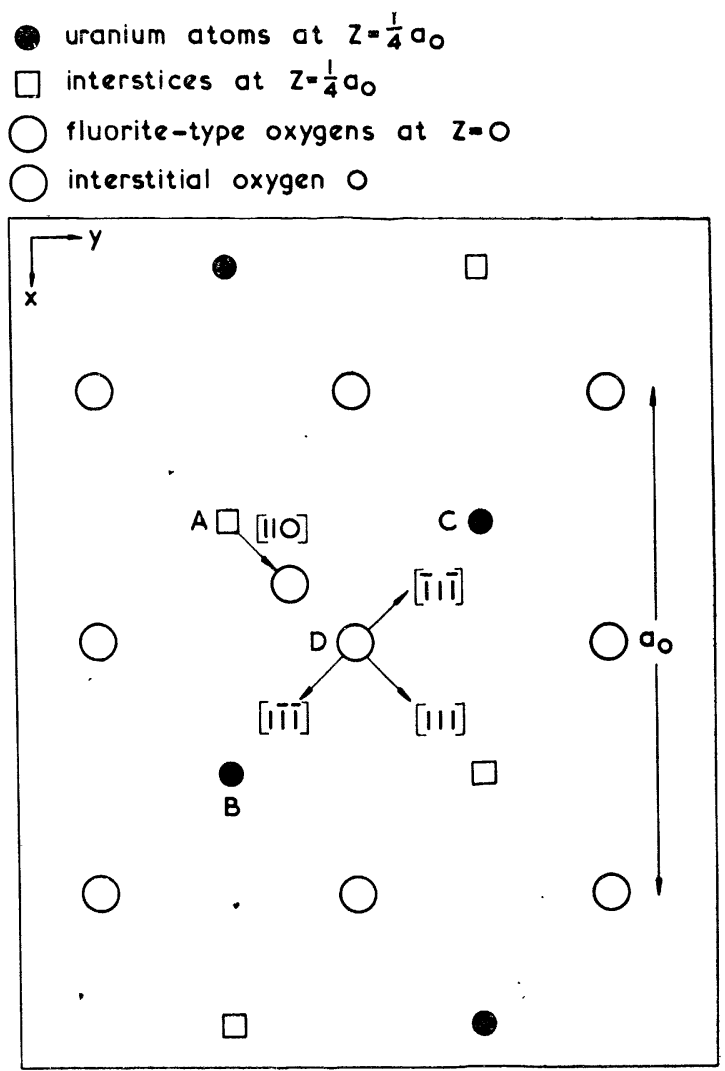

FIG. 5. - Possible mechanism for " polarisation " of interstitial oxygen atoms in $\mathrm{UO}_{2}+\mathrm{x}$ and $\mathrm{U}_{4} \mathrm{O}_{9}$. The interstitial oxygen enters the structure at $A$ but is pulled along [110] by the electrostatic force from uranium atoms $B, C$, which are converted from $\mathrm{U}^{4}+$ to $\mathrm{U}^{5}+$ to maintain charge balance. The fluorite-type oxygen at D is displaced, in turn, along one of the $\langle 111\rangle$ directions shown.

Figure 5 is a diagram illustrating a possible mechanism for the preference of the interstitial atoms in $\mathrm{UO}_{2+x}$ and $\mathrm{U}_{4} \mathrm{O}_{9}$ for $\mathrm{O}^{\prime}$ and $\mathrm{O}^{\prime \prime}$ sites. The oxygen enters the fluorite structure at $A$ but is pulled along [110] by the electrostatic force from uranium atoms $\mathrm{B}, \mathrm{C}$, which are converted from $\mathrm{U}^{4+}$ to $\mathrm{U}^{5+}$ to maintain charge balance. The normal oxygen $D$ is then ejected from its fluorite position in the directions $<111>$ towards the adjacent interstices. This interpretation accounts for the presence of both $\mathrm{O}^{\prime}$ and $\mathrm{O}^{\prime \prime}$ atoms, and predicts that the numbers of $\mathrm{O}$ vacancies and $\mathrm{O}^{\prime \prime}$ atoms are equal, in agreement with the figures quoted in Table III. Any further speculation must await the determination of the full structure of $\mathrm{U}_{4} \mathrm{O}_{9}$ from the measurement of the superlattice reflexions. 
Acknowledgements. - The author wishes to acknowledge the discussion of this work with Dr. J. Williams and Dr L. E. J. Roberts. He is indebted to Dr M. H. Rand for preparing the $\mathrm{U}_{4} \mathrm{O}_{9}$ crystals and to Dr T. L. Markin for measuring their composition.

\section{Discussion}

Pr Watanabe. - N'avez-vous pas examiné une structure basée sur celle de la fluorine et en enlevant des atomes d'uranium de ses positions sans remplir d'oxygène les interstices?

Dr WiLLIs. - Le remplissage complet des sites du type fluorine par les atomes d'uranium est indiqué par des mesures de densité et par la comparaison des intensités avec celles d'un cristal de $\mathrm{UO}_{2}$ placé dans le même faisceau de neutrons. Cependant, un travail supplémentaire est nécessaire pour établir une conclusion définitive.

Pr Post. - La maille $\mathrm{U}_{4} \mathrm{O}_{9}$ offre un volume d'approximativement $18 \AA^{\frac{4}{3}}$ à chaque atome d'oxygène (en négligeant les atomes d'uranium). Ceci semble plutôt faible. Avez-vous calculé les distances $\mathrm{O}-\mathrm{O}$ et certaines sont-elles anormalement courtes?

Dr Willis. - Il n'est pas possible de calculer les distances $\mathrm{O}-\mathrm{O}$, car les résultats exposés sont relatifs à une maille moyenne, obtenue en superposant le continu de 64 mailles de la véritable maille élémentaire.

Dr Andresen. - J'aimerais faire une remarque concernant la surstructure. En 1956, le Dr Frazer et moi-même avons enregistré quelques diagrammes de $\mathrm{U}_{4} \mathrm{O}_{9}$ sur le spectromètre de Corliss et Hastings. Nous avons trouvé que les raies de surstructure ne pouvaient être indexées en système cubique, mème en quadruplant la maille dans toutes les directions. Les raies de surstructures pouvaient au mieux être indexées dans une maille 16 fois plus grande avec un paramètre de $2 a_{0} \sqrt{2}$ dans le plan de base et une hauteur de $2 a_{0}$. Depuis nous avons pensé à plusieurs modèles pour placer les oxygènes supplémentaires mais aucun n'a pleinement réussi. C'est le manque de données suffisantes sur le monocristal qui, apparemment, laisse le problème encore sans solution.

Dr Willis. - Toutes les réflexions, à la fois principales et de surstructure, observées dans la présente étude pouvaient être indexées dans une maille de $4 a_{0}$. Il est possible que d'autres réflexions, nécessitant une plus grande maille n'ont pas été enregistrées, malgré le soin et le temps employé à explorer l'espace réciproque.

Dr Roтн. - Observe-t-on une quelconque diffusion à la température ambiante ?

Dr Willis. - A la température ambiante, $\mathrm{UO}_{2}$ et $\mathrm{U}_{4} \mathrm{O}_{9}$ sont tous deux des structures ordonnées. Aussi ne s'attend-on pas à une diffusion due aux défauts. Elle existe probablement à haute température, mais aucune tentative n'a été faite pour l'observer.

Dr Abrahams. - Les écarts standard pour les facteurs d'occupation de $\mathrm{O}^{\prime}$ et $\mathrm{O}^{\prime \prime}$ sont de l'ordre du 1/60 de celles de $\mathrm{O}$. Y a-t-il une normalisation spéciale pour ces "sigmas " sinon, pourquoi ces erreurs seraient-elles si petites?

Dr Willis. - La corrélation entre les facteurs d'occupation de $\mathrm{O}^{\mathrm{a}}$ et $\mathrm{O}^{\mathrm{b}}$ est responsable de leurs grands écarts standard. Le tableau III montre que l'écart standard pour l'ensemble $\mathrm{O}^{\mathrm{a}}$ et $\mathrm{O}^{\mathrm{b}}$ est comparable à celui pour $\mathrm{O}^{\prime}$ et pour $\mathrm{O}^{\prime \prime}$.

\section{REFERENCES}

[1] Pelle (J.), Uranium dioxide : properties and nuclear applications (U. S. A. E. C.), 1961.

[2] Goldschmidt (V. M.) and Thomassen (L.), Videnskap. Skrift I. Mat.-Nat. Klasse, 1923, p. 1.

[3] Willis (B. T. M.), Proc. Roy. Soc., London, 1963, A 274, 122 .

[4] Willis (B. T. M.), Proc. Roy. Soc., London, 1963, A 274, 134.

[5] Willis (B. T. M.), Nature, 1963, 197, 755.

[6] Alberman (J. K.) and Anderson (J. S.), J. Chem. Soc., Suppl., 1949, p. 5303.

[7] Hering (J.) and Perio (P.), Bull. Soc. Chim. Fr., 1952, 19, 351.

[8] Black burn (P. E.), J. Phys. Chem., 1958, 62, 897.
[9] Roberts (L. E. J.) and Walter (A. J.), J. Inorg. Nucl. Chem., 1961, 22, 213.

[10] Belbeoch (B.), Piekarsie (C.) and Perio (P.), Acta Cryst., 1961, 14, 837.

[11] Markin (T. L.) and Roberts (L. E. J.), Thermodynamics of nuclear materials. I. A. E. A., Vienna, 1962 , p. 693.

[12] Stеe (S.), Naturwiss., 1960, 47, 465.

[13] Arndt (U. W.) and Willis (B. T. M.), Rev. Sc. Instr., 1963, 34, 224 .

[14] Busing (W. R.), Martin (K. O.) and Levy (H. A.), Oak Ridge Report ORNL-TM-305, 1962.

[15] Willis (B. T. M.), J. Brit. Ceram. Soc., 1964, to be published. 